\title{
Effect of Cooking Temperature and Time Period on Phytochemical Content and in vitro Antioxidant and Anti-Inflammatory Activity of the Leaf Extracts of Typhonium trilobatum (A Less Focussed Edible Herbal Plant)
}

\author{
Swati Banerjee $^{1}$, Kamala Adak $^{2}$ \\ ${ }^{1}$ Research Scholar, Department of Home science (Food and Nutrition Division), University of Calcutta, India \\ 20B Judges Court Road, Kol-27 \\ ${ }^{2}$ Associate Professor, Department of Home science (Food and Nutrition Division), University of Calcutta, India \\ 20B Judges Court Road, Kol-27
}

\begin{abstract}
The effect of cooking temperature $\left(100-180^{\circ} \mathrm{c}\right)$ and contact time (10-30min) on the leaf extract of Typhonium trilobatum (Kharkol) was explored for phytochemical profile and in vitro antioxidant activity. The overall objective of this study was to assess the changes in phenolic content and antioxidant and anti-inflammatory activity of $\underline{T}$. trilobatum during heating. Methodology: At each time/temperature combination, total phenolic content, total flavanoid content, total tannin content, DDPH, Hydroxyl (OH), ABTS radical scavenging assay, total antioxidant capacity assay, FRAP assay, Lipid peroxidation inhibition assay, Albumin denaturation assay were analysed. Results: Large diversity in phytochemicals content and antioxidant activity were found with temperature and time variation in comparison to crude extract (unheated). Heating increases total phenolic and antioxidant as well as anti-inflammatory capacity of the sample by liberating the phenolic compounds from their esterified or glycosylated bound form On heating at high temperature, which is relevant to domestic frying $150-180^{\circ} \mathrm{c}$ for $30 \mathrm{~min}$, the leaves showed highest polyphenol (194.86 $\pm 25.07 \mathrm{mg}$ GAE/DE), flavonoids (61.28 $\pm 2.99 \mathrm{GAE} / \mathrm{DE})$ and tannin $(46.77 \pm 1.30 \mathrm{GAE} / \mathrm{DE})$ content. Conclusion: In major cases significant increase in (in vitro) antioxidant capacity is observed on heating at $150^{\circ} \mathrm{c}$ for $10 \mathrm{~min}$. So domestic cooking at this temperature seemed to be optimum for maximum utilization of its antioxidant or disease preventing capacity.
\end{abstract}

Keywords: DPPH, ABTS, Phytochemicals, FRAP, Typhonium trilobatum

\section{Introduction}

There are huge evidences concerning the health promoting and disease preventing potential of plant in dietary context $[1,2]$, and the group of compounds that appear to be key contributors to these potentials are the phytochemicals which are non nutritive, naturally occurring chemical constituents of plants. They are highly valued for their medicinal value of which most important are antioxidant, anti-inflammatory, antimicrobial, antiallergic, antibiotic, hypoglycaemic etc. Phytochemicals, as antioxidants, are highly efficient to scavenge these free radicals and there by inhibit the progression of many degenerative diseases of now-a-days [3]. In food industry there are lots of uses of synthetic antioxidant but these compounds are associated with toxicity and carcinogenic effect. Due to too many side effects of these synthetic antioxidants and several drugs [4], there is an increasing importance on exploration of plant material as a natural source of antioxidant. In this scenario a systematic and planned research work on plant may lead to some fruitful solutions, they are the rich source of phytochemicals. But most dietary vegetables or plants are subjected to thermal treatment in different ways according to the cooking methods and the culinary traditions of the various countries. The application of heat during household cooking encompasses a variety of processes, such as boiling, frying, steaming, baking and roasting, in traditional and microwave ovens.[5] Thermal treatment of foods induces several physical, chemical and biological modifications, leading to sensory, nutritional and textural changes. In plants, phytochemicals serve a wide range of functions, including pigmentation and light capture (e.g anthocyanins, lycopene), defence against insects and diseases (e.g. glucosinolates), Natural phytochemicals show a large diversity of structures, ranging from fairly simple molecules to complex polymers, with or without glycosylation and/or esterification.[6] Polyphenols may be classified into different groups depending on the number of phenol rings and the structural components that bind them together. Four main classes are (i) phenolic acids, (ii) flavonoids, (iii) stilbenes, and (iv) lignans.[7] Their antioxidant activity depends on many structural factors such as number and position of the hydroxyl groups and the degrees of glycosylation, esterification, and polymerization [8]. These compounds behave differently upon processing. In a recent study [9] with T. trilobatum it has been reported that these are precious source of nutrients and phytochemicals in comparison to many expensive commonly used daily leafy vegetables. Further HPLC analysis [10] with these samples established the presence of potential phytochemicals. Since these samples are edible less focussed herbal leafy vegetables, they need cooking or heating before consumption. So, the aim of this work was to analyse the effect of different cooking temperature and time period on the phytochemical content of sample leaf under discussion. To restrict the investigation area, only domestic cooking 


\section{International Journal of Science and Research (IJSR) \\ ISSN (Online): 2319-7064}

Index Copernicus Value (2015): 78.96 | Impact Factor (2015): 6.391

temperature and not industrial transformation processes (for example, cooking extrusion) were taken into account. Typhonium trilobatum belongs to the Araceae family and it is (small to moderate in size) a perennial herb, commonly known as Bengal arum, Ghatkanchu or Ghatkol or Kharkol[11]. It has been valued in Ayurveda and Unani system of medicine for possessing variety of therapeutic properties. There are reports that the rhizome of Typhonium trilobatum has been used for the treatment of vomiting, cough, asthma, excessive expectoration, pyrogenic sore throat, headache, gastric ulcer, abscess, [12,13], diarrhoea and dysentery [14], stimulant and menstrual troubles [15]. Leaves were cooked as vegetables and given to the patient suffering from piles and rheumatism $[16,17]$.

In spite of having potential antioxidant activity, the edible plant leaf remains less focused in our daily diet due to lack of scientific information. In a previous work [9, 10], it has been shown that it is a potent source of nutrients and phytochemicals. To get the beneficial effect it is important to include it into our daily diet with knowledge of the sustaining beneficial effect of phytochemicals due to cooking. Lack of work on such aspect on T. trilobatum insisted the authors to study the effect of different high temperature $\left(100^{\circ} \mathrm{c}, 150^{\circ} \mathrm{c}\right.$ and $\left.180^{\circ} \mathrm{c}\right)$ and different cooking duration $(10,20,30 \mathrm{~min})$ which are relevant to usual domestic cooking on phytochemical content and their antioxidant potential. Hopefully this will be helpful for future studies on related aspects.

\section{Materials and Method}

\subsection{Chemicals}

2,2_-azino-bis(3-ethylbenzothiazoline-6-sulfonate) (ABTS), 2,4,6-tri(2-pyridyl)- s-triazine (TPTZ), FeCl3 6H2O [ferric chloride hexahydrate], 2,2-diphenyl-1-picrylhydrazyl (DPPH), Folin-Ciocalteu reagent, quercetin, gallic acid, catechin were purchased from Sigma Aldrich Chemical Co. (Milwaukee, Wis., U.S.A.) $\mathrm{NaNO}_{2}, \mathrm{AlCl}_{3}, \mathrm{NaOH}, \mathrm{Na}_{2} \mathrm{CO}_{3}$, ammonium acetate, glacial acetic acid, acetyl acetone, ascorbic acid, $\mathrm{Na}_{3} \mathrm{PO}_{4}$, ammonium molybdate, $\mathrm{FeSO}_{4}$, Tricloroacetic acid, Thiobarbituric acid were supplied by E. Merck India

\subsection{Identification and authentication of samples:}

Whole plant of Typhonim trilobatum was submitted to the Herbarium of Calcutta University, Kolkata. One week later its voucher specimen was collected after its identification (Accession No. 20012) which was identified and authenticated by taxonomist of the Calcutta University Herbarium, Kolkata.

\subsection{Sample Collection}

The plant Typhonium trilobatum was collected from different district of west Bengal as well as from different local market.

\subsection{Sample preparation}

The leaves were shade dried for 3-4 days and grounded into powder and stored for further study

\subsection{Determination of total polyphenol content}

To measure the total polyphenol content, Folin-Ciocalteu assay was employed [18]. $0.2 \mathrm{~mL}$ of $80 \%$ methanolic extract of samples $(1 \mathrm{mg} / \mathrm{ml})$ was added with $1 \mathrm{~mL}$ of FolinCiocalteu's phenol reagent (10 fold diluted). $0.8 \mathrm{~mL}$ of $2 \%$ $\mathrm{Na}_{2} \mathrm{CO}_{3}$ and $60 \%$ methanol were added successively. Then the reaction mixture was incubated at room temperature for $30 \mathrm{~min}$ and were spectrophotometrically analysed at $740 \mathrm{~nm}$. The calibration curve was plotted using gallic acid (20-100 $\mathrm{mg} / \mathrm{ml}$ ) as standard and the result of polyphenol content was represented as $\mathrm{mg}$ of gallic acid equivalent per $\mathrm{g}$ of dry extract.

\subsection{Determination of flavonoid content}

Aluminium chloride method [19] was used to quantify total flavonoid content. An aliquot of extracts $(0.1 \mathrm{ml})$ or the standard solution of quercetin (20 to $100 \mathrm{mg} / \mathrm{ml}$ ) was added to a $10 \mathrm{ml}$ volumetric flask containing $4 \mathrm{ml}$ of distilled water. $0.3 \mathrm{ml} 5 \% \mathrm{NaNO}_{2}$ was added. After $5 \mathrm{~min}, 0.3 \mathrm{ml}$ $10 \% \mathrm{AlCl}_{3}$ was added. At 6th min, $2 \mathrm{ml} 1 \mathrm{M} \mathrm{NaOH}$ was added and the total volume was made up to $10 \mathrm{ml}$ with distilled water. The absorbance was measured at $510 \mathrm{~nm}$ and the results were expressed as $\mathrm{mg}$ of quercetin equivalent per $\mathrm{g}$ of dry extract.

\subsection{Determination of Total Hydrolysable Tannin Content (HTC)}

Content of tannins was determined by Folin-Denis method [20] $.0 .5 \mathrm{gm}$ of dry sample was added to $75 \mathrm{ml}$ of distilled water, boiled for 30 minutes. Then it was centrifuged. The supernatant liquid was collected and made up to the volume of $100 \mathrm{ml}$ by distilled water. $0.1 \mathrm{ml}$ of this solution, $7.5 \mathrm{ml}$ of water, $0.5 \mathrm{ml}$ of Folin-Denis reagent and $1 \mathrm{ml}$ of $35 \%$ $\mathrm{Na}_{2} \mathrm{CO}_{3}$ were added to it. The volume was made up to $10 \mathrm{ml}$ by using distilled water and shaken well. After incubation for 30 minutes at room temperature, the absorbance was measured at $700 \mathrm{~nm}$ against a tannic acid standard calibration curve $(20-100 \mathrm{mg} / \mathrm{ml})$

\subsection{FRAP Assay}

FRAP values were evaluated by the method of Benzie and Strain [21]. To prepare working FRAP reagent, $50 \mathrm{ml}$ of 300 $\mathrm{mM}$ acetate buffer (pH-3.6) was mixed with $5 \mathrm{ml}$ of $40 \mathrm{mM}$ TPTZ (2, 4, 6-tripyridyl-s-triazine) dissolved in $40 \mathrm{mM} \mathrm{HCl}$ and $5 \mathrm{ml}$ of $20 \mathrm{mM} \mathrm{FeCl}_{3} .100 \mu \mathrm{g}$ of extract was added to 3 $\mathrm{ml}$ of freshly prepared working FRAP reagent. The absorbance at $593 \mathrm{~nm}$ was measured immediately and after 4 min of incubation at $37{ }^{\circ} \mathrm{C}$. The change in absorbance was recorded as the final absorbance. For plotting calibration curve, $\mathrm{FeSO}_{4} .7 \mathrm{H}_{2} \mathrm{O}$ was used as standard at various concentrations $(100-500 \mu \mathrm{M} / 1)$. The ferric reducing ability of sample was expressed as FRAP value $\left(\mu \mathrm{M}\right.$ of $\mathrm{Fe}^{2+}$ equivalent). 


\section{International Journal of Science and Research (IJSR) \\ ISSN (Online): 2319-7064}

Index Copernicus Value (2015): 78.96 | Impact Factor (2015): 6.391

\subsection{DPPH radical scavenging activity}

DPPH (2, 2-diphenyl-1-picrylhydrazyl) radical scavenging activity was evaluated by the method of Hsu et al., 2007 [22] with minor modifications. $3 \mathrm{ml}$ of $0.1 \mathrm{mM}$ DPPH solution was mixed with $1 \mathrm{ml}$ of various concentrations (100 to 300 $\mu \mathrm{g} / \mathrm{ml})$ of leaf extract. The mixture was shaken vigorously and incubated at room temperature for $30 \mathrm{~min}$ in the dark. The reduction of the DPPH free radical was measured by reading the absorbance at $517 \mathrm{~nm}$ by a spectrophotometer against methanol blank. . The solution without any extract and with DPPH and methanol was used as control. The percentage of inhibition DPPH radical was calculated as: [(Absorbance of control - Absorbance of sample)/ Absorbance of control] X 100.

$\mathrm{IC}_{50}$ value of each sample was determined from the graph between sample concentration and the percentage of DPPH radical inhibition.

\subsection{Hydroxyl radical scavenging activity}

To evaluate the hydroxyl radical scavenging activity, the method as described by Singh [23] was used. Different concentrations $(50,100$ and $150 \mu \mathrm{g})$ of sample extracts were taken separately in tubes. $1 \mathrm{ml}$ of Iron EDTA $(0.1 \%$ ferrous ammonium sulphate and $0.26 \%$ EDTA) was mixed with 0.5 $\mathrm{ml}$ of EDTA $(0.018 \%)$ and $1 \mathrm{ml}$ of DMSO $(0.85 \%$ in $0.1 \mathrm{M}$ phosphate buffer with $\mathrm{pH} 7.4)$. To commence the reaction $0.5 \mathrm{ml}$ of ascorbic acid $(0.22 \%)$ was added and held in a water bath at $80-90{ }^{\circ} \mathrm{C}$ for $15 \mathrm{~min} .1 \mathrm{ml}$ of ice cold TCA was added to stop the reaction. $3 \mathrm{ml}$ of Nash reagent ( $75 \mathrm{~g}$ of ammonium acetate was mixed with $3 \mathrm{ml}$ of glacial acetic acid and $2 \mathrm{ml}$ of acetyl acetone and the volume was made upto $1 \mathrm{~L}$ with distilled water) was finally added and incubated for $15 \mathrm{~min}$ at room temperature for yellow colour development. Then the absorbance was taken at $412 \mathrm{~nm}$ against reagent blank. Percentage of hydroxyl radical scavenging activity was calculated as follows:

[1 - (sample absorbance $\backslash$ control absorbance)] X100.

The hydroxyl radical scavenging activity is expressed as $\mathrm{EC}_{50}$.

\subsection{Total antioxidant activity by the phosphomolybdenum method}

The total antioxidant activities of the plant leaf extract were evaluated by the phosphomolybdenum complex formation method [24] .100-300 $\mu \mathrm{g}$ different concentration of each leaf extract were added to test tube containing $3 \mathrm{ml}$ of distilled water and mixed with $1 \mathrm{ml}$ of reagent solution $(0.6 \mathrm{M}$ $\mathrm{H}_{2} \mathrm{SO}_{4}, \quad 28 \quad \mathrm{mM} \quad \mathrm{Na}_{3} \mathrm{PO}_{4}$ and $4 \mathrm{mM}$ ammonium molybdate).The vials were capped and incubated in water bath at $95{ }^{\circ} \mathrm{C}$ for 90 minutes. After, cooling, the absorbance was measured at $695 \mathrm{~nm}$ against the reagent blank. The antioxidant activity is measured against an ascorbic acid calibration curve.

\subsection{In vitro lipid peroxidation inhibition assay}

Freshly excised goat liver was processed to get $10 \%$ homogenate in cold phosphate buffer saline, $\mathrm{pH}-7.4$ using homogenizer and filtered to get clear homogenate. The degree of lipid peroxidation was assessed by TBARS standard method [25] with minor modification [26]. Different concentration (100-300 $\mu \mathrm{g})$ of crude leaf extract was added to liver homogenate. Lipid peroxidation was initiated by adding $100 \mu \mathrm{l}$ of $15 \mathrm{mM} \mathrm{FeSO}_{4}$ solution to $3 \mathrm{ml}$ of tissue homogenate. After $30 \mathrm{~min}, 100 \mu \mathrm{l}$ of this reaction mixture was taken in a tube containing $1.5 \mathrm{ml}$ of $10 \%$ TCA. After 10 min tubes were centrifuged and supernatant was separated and mixed with $1.5 \mathrm{ml}$ of $0.67 \%$ TBA in $50 \%$ acetic acid. The mixture was heated for $30 \mathrm{~min}$ in boiling water bath. The intensity of pink coloured complex formed was measured at $535 \mathrm{~nm}$. A control was prepared without any sample. The percentage inhibition was calculated by using the formula below.

[(Absorbance of control - Absorbance of sample)/ Absorbance of control] X 100.

The results were expressed as $\mathrm{IC}_{50}$ Value.

\subsection{Inhibition of albumin denaturation}

Method of Mizushima et al [27] was followed with minor modifications. The reaction mixture, consisting of test extract at different concentrations (100-300 $\mu \mathrm{g})$ and $1 \%$ aqueous solution of bovine albumin fraction were incubated at $37^{\circ} \mathrm{C}$ for $20 \mathrm{~min}$ and then heated at $51^{\circ} \mathrm{C}$ for $20 \mathrm{~min}$. After cooling the samples, the turbidity was measured spectrophotometrically at $660 \mathrm{~nm}$. Percent inhibition of protein denaturation was calculated as follows and $\mathrm{IC}_{50}$ value was calculated.

Percentage inhibition $(\%)=\left[\left(\mathrm{Abs}_{\text {control }}-\mathrm{Abs}_{\text {sample }}\right) /\right.$ $\left.\mathrm{Abs}_{\text {control }}\right] \mathrm{X} 100$

The results were expressed as $\mathrm{IC}_{50}$ Value.

2.14 Determination of $\operatorname{ABTS}^{+}[2,2$-azino-bis (3ethylbenzthiazoline-6-sulfonic acid)] scavenging activity

For ABTS assay, the method of Dimitrina (2010) and Roberta (1999) with some modifications was followed [28, 29]. ABTS was dissolved in water to make a concentration of $7 \mathrm{mmol} / \mathrm{L}$. ABTS+ was produced by reacting the ABTS stock solution with $2.45 \mathrm{mmol} / \mathrm{L}$ potassium persulfate and allowing the mixture to stand in the dark at room temperature for $12-16 \mathrm{~h}$ before use.

For the test of samples, the ABTS + stock solution was diluted with $80 \%$ methanol to an absorbance of $0.70 \pm 0.02$ at $734 \mathrm{~nm} .4 .85 \mathrm{ml}$ of diluted ABTS+ was added to $0.15 \mathrm{ml}$ of samples solution of different con. (100-300 $\mu \mathrm{g})$, and the absorbance was taken 6 min after the initial mixing. BHT $(0.1 \mathrm{mg} / \mathrm{ml})$ was used as standard. The activities of the samples were evaluated by comparison with a control (containing $4.85 \mathrm{ml}$ of ABTS solution and $0.15 \mathrm{ml}$ of $80 \%$ Methanol). This activity is given as percentage ABTS+ scavenging that is calculated by the following formula:

ABTS+ scavenging activity $(\%)=\left[\left(\mathrm{Abs}_{\text {control }}-\mathrm{Abs}_{\text {sample }}\right) /\right.$ $\left.\mathrm{Abs}_{\text {control }}\right] \mathrm{X} 100$.The results were expressed as $\mathrm{EC}_{50}$.

\section{Statistical Analysis}

Statistical Analysis was performed with help of SPSS 17. Descriptive statistical analysis was performed to calculate 


\section{International Journal of Science and Research (IJSR) \\ ISSN (Online): 2319-7064}

Index Copernicus Value (2015): 78.96 | Impact Factor (2015): 6.391

the means with corresponding standard deviation (SD). Also One Way Analysis of variance (ANOVA) followed by post hoc Tukey's test was performed to compare the mean values. $\mathrm{p}<0.05$ was taken to be statistically significant.

\section{Result and Discussion}

Table 1: Comparison of Yield percentage and Phytochemical content of T. trilobatum at different high temperature and time.

\begin{tabular}{|c|c|c|c|c|c|}
\hline $\operatorname{Temp}{ }^{\circ} \mathrm{C}$ & Time(min) & $\begin{array}{c}\text { Yield percentages } \\
\text { \%gm }\end{array}$ & $\begin{array}{c}\text { Total polyphenol content } \\
\text { mg/g extract }\end{array}$ & $\begin{array}{c}\text { Total flavonoid } \\
\text { content mg/g extract }\end{array}$ & $\begin{array}{c}\text { Toatal tannin } \\
\text { content } m g / g \text { extract }\end{array}$ \\
\hline Raw & & $19.83^{\mathrm{a}} \pm .39$ & $106.65^{\mathrm{a}} \pm 3.99$ & $40.77^{\mathrm{a}} \pm 6.36$ & $17.17^{\mathrm{a}} \pm 0.82$ \\
\hline 100 & 10 & $25.25^{\mathrm{b}} \pm .62$ & $121.96^{\mathrm{b}} \pm 2.37$ & $43.64^{\mathrm{ab}} \pm 5.40$ & $20.27^{\mathrm{b}} \pm 0.74$ \\
\hline 150 & 10 & $29^{c} \pm 2.86$ & $133.17^{\mathrm{bc}} \pm 6.86$ & $50.31^{\text {bcd }} \pm 5.97$ & $36.67^{\mathrm{e}} \pm 1.49$ \\
\hline 180 & 10 & $16.5^{\mathrm{d}} \pm .79$ & $136.96^{\mathrm{cd}} \pm 6.10$ & $52.05^{\mathrm{cde}} \pm 3.20$ & $39.64^{\mathrm{f}} \pm 0.31$ \\
\hline 100 & 20 & $36.67^{f} \pm .65$ & $136.34^{\mathrm{cd}} \pm 3.34$ & $46.99^{\mathrm{abc}} \pm 6.28$ & $29.84^{\mathrm{c}} \pm 1.78$ \\
\hline 150 & 20 & $30.17^{\mathrm{de}} \pm .72$ & $144.88^{\mathrm{cd}} \pm 8.85$ & $55.27^{\mathrm{def}} \pm 5.35$ & $41.34^{\mathrm{g}} \pm 0.91$ \\
\hline 180 & 20 & $19.58^{\mathrm{ag}} \pm .79$ & $147.43^{\mathrm{de}} \pm 2.17$ & $54.73^{\mathrm{def}} \pm 4.73$ & $38.37^{\mathrm{f}} \pm 0.78$ \\
\hline 100 & 30 & $22.50^{\mathrm{h}} \pm .79$ & $137.25^{\mathrm{cd}} \pm 3.41$ & $48.72^{\text {bcd }} \pm 7.82$ & $34.41^{\mathrm{d}} \pm 1.03$ \\
\hline 150 & 30 & $33.67^{\mathrm{i}} \pm .65^{\mathrm{i}}$ & $160.68^{\mathrm{ef}} \pm 10.83$ & $61.28^{\mathrm{fg}} \pm 2.99$ & $46.77^{i} \pm 1.30$ \\
\hline 180 & 30 & $9.58^{\mathrm{j}} \pm .67$ & $194.86^{\mathrm{g}} \pm 25.07$ & $59.44^{\mathrm{fg}} \pm 2.59$ & $30.35^{\mathrm{c}} \pm 1.71$ \\
\hline
\end{tabular}

Values are represented as mean $\pm \mathrm{SD}$. Values followed by different superscript letter(s) within each column are significantly different at $P<0.05$ by Tukey test.

This table shows that there is wide variation in the yield percentages of leaf extract of Kharkol with change of temperature and time duration. The highest yield percentage $(36.67 \pm .65 \mathrm{gm})$ was noticed at $100^{\circ} \mathrm{C}(20 \mathrm{~min})$ for Kharkol leaves.

The results suggest the sample is potential source of polyphenol but the rise of temperature and increase of time duration showed a sharp upward trend and the results suggest that high temperature $180^{\circ} \mathrm{c}$ and long time duration (30min) are optimum for polyphenol extraction It is supported by previous work where Naeem et al., 2012, [30] stated that temperature has significant influence on the phenolic content, where the highest content was reported at the highest temperature due to the increase in both the solubility of the solute and diffusion coefficient. Three possible mechanisms have been proposed to explain the changes of phenolic content of samples exposed to high temperature [31] these mechanisms include the release of bound phenolic compounds, the partial degradation of lignin leading to the release of phenolic acid derivatives, and the beginning of thermal degradation of the phenolic compounds. Resistance to high temperature against thermal degrations may be due to higher content of condensed tannin. The increase in total polyphenol content may be explained by the liberation of phenolic compounds [32].

A significant increase in TFC was observed when the sample was heated up to $180^{\circ} \mathrm{c}$ The highest TFC, $(61.28 \pm 2.99 \mathrm{mg} / \mathrm{g}$ extract) was revealed at a heating temperature of $\left(150^{\circ} \mathrm{c}\right)$ for $30 \mathrm{~min}$ compared to the unheated raw. It is supported by previous study where Sathishkumar et al., 2008,[33] showed that at higher temperatures, flavonoids diffused more quickly from the cell to the extracting solvent.

Tannin content showed an upward trend with rise of temperature upto $150^{\circ} \mathrm{C}$ and $30 \mathrm{~min}$ duration for Kharkol leaves. Highest value $(\mathbf{4 6 . 7 7} \pm \mathbf{1 . 3 0} \mathbf{~ m g} / \mathbf{g}$ extract$)$ observed at this temperature and time period.

Table 2: In vitro antioxidant assay at different temperature and time period of Typhonium trilobatum leaf extract.

\begin{tabular}{|c|c|c|c|c|c|c|c|c|}
\hline $\begin{array}{c}\text { Temp } \\
{ }^{\circ} \mathrm{C}\end{array}$ & $\begin{array}{l}\text { Time } \\
\text { (min) }\end{array}$ & $\begin{array}{c}D P P H \\
I C_{50} \text { value } \mu g\end{array}$ & $\begin{array}{c}A B T S \\
E C_{50} \text { value } \mu g\end{array}$ & $\begin{array}{l}\mathrm{OH} \mathrm{IC}_{50} \\
\text { value } \mu \mathrm{g}\end{array}$ & $\begin{array}{l}L P I C_{50} \\
\text { value } \mu g\end{array}$ & $\begin{array}{c}\text { FRAP mMFe } \mathrm{Fe}^{++} \\
\text {equivalent }\end{array}$ & $\begin{array}{l}T A C \\
m g / g\end{array}$ & $\begin{array}{c}A D \\
I C_{50} \text { value } \mu g\end{array}$ \\
\hline Raw & & $425.82^{\mathrm{ef}} \pm 28.65$ & $176.01^{\text {def }} \pm 16.88$ & $1406.73^{\mathrm{e}_{1}} \pm 100.97$ & $1347.10^{f} \pm 49.39$ & $546.62^{\mathrm{a}} \pm 19.38$ & $179.02^{\mathrm{a}} \pm 16.48$ & $168.09^{i} \pm 1.95$ \\
\hline 100 & 10 & $409.86^{\mathrm{de}} \pm 36.53$ & $141.66^{\text {bcd }} \pm 42.73$ & $344.12^{\mathrm{c}} \pm 27.08$ & $725.37^{\mathrm{c}} \pm 36.67$ & $612.61^{\mathrm{ab}} \pm 71.25$ & $224.00^{\mathrm{b}} \pm 11.55$ & $87.64^{\mathrm{b}} \pm 1.16$ \\
\hline 150 & 10 & $254.99^{\mathrm{a}} \pm 22.40$ & $100.50^{\mathrm{a}} \pm 14.59$ & $179.04^{\mathrm{a}} \pm 5.27$ & $321.32^{a} \pm 38.10$ & $1073.36^{\mathrm{fg}} \pm 126.89$ & $258.11^{\mathrm{cde}} \pm 29.88$ & $84.22^{\mathrm{a}} \pm 1.56$ \\
\hline 180 & 10 & $279.78^{\mathrm{a}} \pm 19.86$ & $126.88^{\mathrm{abc}} \pm 18.60$ & $493.16^{\mathrm{d}} \pm 32.98$ & $350.15^{\mathrm{a}} \pm 21.00$ & $970.08^{\mathrm{ef}} \pm 71.66$ & $228.26^{\mathrm{b}} \pm 16.77$ & $112.41^{f} \pm 2.29$ \\
\hline 100 & 20 & $412.84^{\mathrm{ef}} \pm 33.54$ & $120.17^{\mathrm{ab}} \pm 35.81$ & $366.60^{c} \pm 16.61$ & $377.91^{\mathrm{a}} \pm 35.02$ & $685.46^{b c} \pm 118.03$ & $249.65^{\mathrm{bcd}} \pm 9.99$ & $106.15^{\mathrm{c}} \pm 1.66$ \\
\hline 150 & 20 & $333.10^{\mathrm{b}} \pm 25.67$ & $105.79^{\mathrm{ab}} \pm 19.16$ & $244.98^{\mathrm{b}} \pm 9.58$ & $352.24^{\mathrm{a}} \pm 13.00$ & $911.10^{\mathrm{de}} \pm 78.39$ & $279.69^{\mathrm{efg}} \pm 32.27$ & $108.08^{\mathrm{cd}} \pm 1.24$ \\
\hline 180 & 20 & $349.32^{\mathrm{bc}} \pm 41.40$ & $163.97^{\text {cde }} \pm 32.01$ & $518.52^{\mathrm{d}} \pm 26.70$ & $440.46^{\mathrm{b}} \pm 8.32$ & $880.65^{\mathrm{de}} \pm 100.82$ & $232.39^{b c} \pm 15.95$ & $134.30^{\mathrm{h}} \pm 2.62$ \\
\hline 100 & 30 & $361.48^{\mathrm{bc}} \pm 20.96$ & $108.98^{\mathrm{ab}} \pm 33.25$ & $388.42^{\mathrm{c}} \pm 11.04$ & $461.72^{b} \pm 23.13$ & $697.14^{b c} \pm 62.48$ & $263.72^{\mathrm{def}} \pm 9.95$ & $130.62^{\mathrm{g}} \pm 2.14$ \\
\hline 150 & 30 & $340.14^{\mathrm{bc}} \pm 26.51$ & $130.01^{\mathrm{abc}} \pm 33.45$ & $261.26^{\mathrm{b}} \pm 9.39$ & $814.29^{\mathrm{d}} \pm 34.19$ & $847.90^{\mathrm{d}} \pm 46.42$ & $286.39^{\mathrm{fg}} \pm 28.00$ & $109.61^{\mathrm{de}} \pm 1.34$ \\
\hline 180 & 30 & $373.92^{\mathrm{cd}} \pm 27.68$ & $180.09^{\mathrm{def}} \pm 40.91$ & $1024.92^{f} \pm 43.87$ & $1004.52^{\mathrm{e}} \pm 44.52$ & $847.00^{\mathrm{d}} \pm 61.34$ & $309.23^{\mathrm{ij}} \pm 27.03$ & $244.86^{\mathrm{j}} \pm 2.29$ \\
\hline
\end{tabular}

Values are represented as mean \pm SD. Values followed by different superscript letter(s) within each column are significantly different at $P<0.05$ by Tukey test.

DPPH is stable nitrogen centered free radical and is extensively used for determining antioxidant activity. DPPH assay measures hydrogen (or electron) donating ability of the samples thereby changing DPPH radical from purple to yellow colour and converting it to its reduced form [34]. The results were expressed as $\mathrm{IC}_{50}$ value so, lower $\mathrm{IC}_{50}$ values indicates better free radical (DPPH) scavenger. Result showed that the samples are able to scavenge DPPH with respect to BHT standard $\left(\mathrm{IC}_{50} 28.19 \pm 1.80 \mu \mathrm{g}\right) .150^{\circ} \mathrm{C}-10$ min time-temp variations proved to be the optimum

\section{Volume 6 Issue 1, January 2017




\section{International Journal of Science and Research (IJSR) \\ ISSN (Online): 2319-7064}

Index Copernicus Value (2015): 78.96 | Impact Factor (2015): 6.391

condition in case of Kharkol leaves, to obtain its highest antioxidant activity $\left(254.99^{\mathrm{a}} \pm 22.40 \mu \mathrm{g}\right)$. As temperature was increased, the scavenging potential of Kharkol leaves showed linear trend upto $150^{\circ} \mathrm{C}$ and the trend broke at $180^{\circ} \mathrm{C}$. But time duration had significant effect on the antioxidant activity as it continued to increase orderly with time for $100^{\circ} \mathrm{C}$ but reverse effect observed after $150^{\circ} \mathrm{C}$.

ABTS is also frequently used by the food industry and agricultural researchers to measure the antioxidant capacities of foods. In this assay, ABTS is converted to its radical cation by addition of potassium persulfate. This radical cation is blue in colour and absorbs light at $734 \mathrm{~nm}$. The ABTS radical cation is reactive towards most antioxidants including phenolics, thiols and ascorbic acid. During this reaction, the blue ABTS radical cation is converted back to its colourless neutral form. Though, the sample leaf extracts is able to scavenge ABTS radical cation in terms of $\mathrm{EC}_{50}$, Kharkol leaf extract showed highest activity $(100.50 \pm 14.59$ $\mu \mathrm{g})$ at $150^{\circ} \mathrm{C}(10 \mathrm{~min})$. Temperature increase upto $150^{\circ} \mathrm{C}$ revealed positive effect on the the ability of scavenging radical but further increase in temperature and time length from $10-30 \mathrm{~min}\left(\operatorname{except} 100^{\circ} \mathrm{C}\right)$ decreased the ability.

Hydroxyl radical is known to cause lipid peroxidation and cellular damage in significant proportions by removing hydrogen atoms from unsaturated fatty acids. Hydroxyl radicals generated by ascorbic acid, iron and EDTA inside in vitro system are reduced significantly due to the hydroxyl radical scavenging activity of samples. It is formed as a consequence of oxidation reaction with DMSO to yield formaldehyde. This was detected by treatment with Nash reagent [35]. $\mathrm{EC}_{50}$ value of ascorbic acid which is used as standard is $72.50 \pm 1.14 \mu \mathrm{g}$ Study suggest that in raw condition in this assay which depends on the structure of the antioxidant [39]. The phosphomolybdenum method usually detects antioxidants such as ascorbic acid, some phenolics, tocopherols and carotenoids. Ascorbic acid was used as standard to prepare the calibration curve. Highest activity (309.23 $\pm \mathbf{2 7 . 0 3 )}$ is observed for Kharkol leaves at $180^{\circ} \mathrm{C}$ (30min).

Protein Denaturation is a process in which proteins lose their tertiary and secondary structure by application of external stress due to the presence of compounds like strong acid, a sample was able to scavenge hydroxyl radical but with increasing temperature Kharkol became more potent both at $100^{\circ} \mathrm{C}(10 \mathrm{~min})$ and $150^{\circ} \mathrm{C}(10 \mathrm{~min}, 20 \mathrm{~min}, 30 \mathrm{~min})$. Further increase of temperature $180^{\circ} \mathrm{C}$ and time duration $(10 \mathrm{~min}-$ $20 \mathrm{~min}-30 \mathrm{~min}$ ) resulted in decrease of activity.

Lipid peroxidation is the oxidative degration of PUFA and involves formation of lipid radicals leading to membrane damage. Free radicals induce lipid peroxidation in PUFA rich areas like brain and liver [36]. Initiation of lipid peroxidation by $\mathrm{FeSO}_{4}$ takes place through hydroxy radical by Fenton reaction[37]. The inhibition could be caused by absence of ferryl-perferryl complex or by scavenging hydroxy radical or superoxide radical or by changing the $\mathrm{Fe}^{3+} / \mathrm{Fe}^{2+}$ or by reducing the rate of conversion of ferrous to ferric or by chelating the iron itself. Present result show that the leaf extract has potential to inhibit the generation of lipid peroxides with respect to BHT standard $\left(\mathrm{IC}_{50} 60.67 \mu \mathrm{g}\right)$, The highest potentials exhibited $\left(321.32^{\mathrm{a}} \pm 38.10\right)$ at $150^{\circ} \mathrm{C}$ (10min).

FRAP assay is based on the capability of the sample to reduce the $\mathrm{Fe}^{3}+$ to $\mathrm{Fe}^{2}+$ in the presence of TPTZ, forming a blue coloured Ferrous - TPTZ complex with an absorption maxima at $593 \mathrm{~nm}$ [38]. The mean FRAP values, expressed as Fe (II) $(\mu \mathrm{M}) / \mathrm{g}$ of dry extract. The highest value of sample $\left(1073.36^{\mathrm{fg}} \pm 126.89\right)$ was obtained at $150^{\circ} \mathrm{C}$ for $10 \mathrm{~min}$. So the reducing capacity of heated samples was better than raw samples upto $150^{\circ} \mathrm{C}$ temperature.

Total antioxidant capacity is based on the reduction of molybdenum (VI) to molybdenum (V) by the antioxidants and the subsequent formation of a green phosphate Mo (V) complex at acidic $\mathrm{pH}$ values. Electron transfer occurs base, a concentrated solution of inorganic salt and an organic solvent or by heat. Denaturation of proteins is a well documented cause of inflammation [40]. Aspirin, a standard anti-inflammation drug showed the $\mathrm{IC}_{50}$ at $73.53 \mu \mathrm{g}$, which suggest that the sample was quite potent in inhibiting albumin denaturation as well as inflammation which correlates with their uses in traditional medicine. Increase in temperature result in better ability than raw unheated condition and maximum inhibition was $\left(84.22^{\mathrm{a}} \pm 1.56\right)$ observed at $150^{\circ} \mathrm{C}$ for $10 \mathrm{~min}$ in terms of $\mathrm{IC}_{50}$ for Kharkol leaves.

Table 3: Correlation matrix (Pearson's correlation coefficient) between various mean values of antioxidant assay of Kharkol leaf extract

\begin{tabular}{|c|c|c|c|c|c|c|c|c|c|}
\hline & FRAP & TAN & $P O L Y$ & TAC & FLAV & $D P P H$ & $A B T S$ & $L P$ & $A L$ \\
\hline TAN & $.681^{* * *}$ & & $.587^{* *}$ & $.693^{k *}$ & .038 & $-.726^{* * *}$ & $-.331^{* * *}$ & $-.411^{* *}$ & -.057 \\
\hline$P O L Y$ & $.530^{* * *}$ & $.587^{* * *}$ & & $.739^{* * *}$ & $.306^{* * *}$ & $-.732^{* * *}$ & $.225^{*}$ & -.003 & $.532^{* * *}$ \\
\hline$T A C$ & $.468^{* * *}$ & $.693^{* * *}$ & $.739^{* * *}$ & & -.103 & $-.630^{* * *}$ & $-.217^{*}$ & $-.204^{*}$ & $.205^{*}$ \\
\hline FLAV & .089 & .038 & $.306^{* * *}$ & -.103 & & $-.444^{* * *}$ & $.502^{* * *}$ & $.475^{* *}$ & $.571^{* * *}$ \\
\hline$D P P H$ & $-.585^{* * *}$ & $-.726^{* *}$ & $-.732^{* * *}$ & $-.630^{* * *}$ & $-.444^{* * *}$ & & $\begin{array}{l}.030 \\
\end{array}$ & $\begin{array}{l}-.002 \\
\end{array}$ & $-.253^{* * *}$ \\
\hline$A B T S$ & -.110 & $-.331^{* *}$ & $.225^{*}$ & $-.217^{*}$ & $.502^{* * *}$ & -.030 & & $.504^{* * *}$ & $.519^{* * *}$ \\
\hline$L P$ & $-.373^{* * *}$ & $-.411^{* *}$ & -.003 & $-.204^{*}$ & $.475^{* * *}$ & -.002 & $.504^{* * *}$ & & $.624^{* * *}$ \\
\hline$A D$ & .053 & -.057 & $.532^{* * *}$ & $.205^{*}$ & $.571^{* * *}$ & $-.253^{* * *}$ & $.519^{* * *}$ & $.624^{* * *}$ & \\
\hline $\mathrm{OH}$ & $-.311^{* * *}$ & $-.493^{* * *}$ & $\begin{array}{l}-.033 \\
\end{array}$ & $-.341^{* * *}$ & $.552^{* * *}$ & $.202^{*}$ & $.548^{* * *}$ & $.827^{* *}$ & $.775^{* * *}$ \\
\hline
\end{tabular}

*Correlation is significant at the 0.05 level. ** Correlation is significant at the 0.01 level.

Result suggest that there is strong correlation (significant at 0.01 level) between the antioxidant assay in term of DPPH, FRAP, total antioxidant capacity Albumin denatunation (in vitro anti-inflammatory assay), and the polyphenol content of Kharkol. A high correlation is observed between DPPH, FRAP, ABTS, Lipid peroxidation, $\mathrm{OH}$ radical scavenging 


\section{International Journal of Science and Research (IJSR) \\ ISSN (Online): 2319-7064}

Index Copernicus Value (2015): 78.96 | Impact Factor (2015): 6.391

potential and Tannin. A correlation is also observed between the DPPH and flavonoid content.

\section{Conclusion}

The result of TPC and TFC content, together with the DPPH, ABTS, OH radical scavenging ability, lipid peroxidation, albumin denaturation and FRAP reducing potential, all demonstrated that $T$. trilobatum is rich in polyphenolic products with high antioxidant activity against various free radicals. In a previous scientific study of the authors, the polyphenolic profile of the leaf extract also showed the presence of specific phytochemicals as quercetin, catechin and gallic acid. The application of heat at temperatures and times similar to domestic boiling, sautéing, frying showed that higher heating temperatures $\left(150-180^{\circ} \mathrm{C}\right)$ and shorter heating period caused an increase in the antioxidant capability of the sample. This study intends to highlight the valuable fact that only simple domestic cooking temperature brings about increase in disease preventing capacity and this does not require any techniques which are followed in pharma ceutical industry. Both polyphenol and flavonoid content have been observed to possess strong positive correlations with the antioxidant activities determined by DPPH, ABTS, OH radical, FRAP lipid peroxidation and albumin denaturation (marker of in vitro anti-inflammatory assay) and the antioxidant activity of the sample is observed to be related to the presence of those particular compounds. Cooking for short time does not impact any negative effect on its valuable phytochemical content rather than these results indicate that thermal effect has positive impact on its antioxidant potentials. From the findings of present work, the highest activity for Kharkol leaves was observed at $150^{\circ} \mathrm{C}$ (with few exceptions). So cooking at $150^{\circ} \mathrm{C}$, which is relevant to domestic sautéing and frying for 10 minutes is recommended for maximum utilisation of its antioxidant potential. Since the phytochemicals of sample are not heat sensitive, further extensive work on them may link to a route to a horizon of drug development.

\section{References}

[1] L.C.Tapsell, I. Hemphill, L. Cobiac. Health benefits of herbs and spices: the past, the present, the future," The medical journal of Australia, 185, (4), S4-24, 2006.

[2] M.Viuda-Martos, Y. Ruiz-Nvajas, J. Fernandez-Lopez, J. A. Perez-Alvarez. "Spices as functional foods", Critical Reviews in Food Science and Nutrition, 51, (1), 13-28, 2011.

[3] T. Ghosh, K.T. Maity, P. Sengupta, K.D. Dash, A. Bose. Antidiabetic and in vivo antioxidant activity of ethanolic extract of Bacopa monnieri Linn. aerial parts: apossible mechanism of action. Iranian J. Pharm. Res, 7, 61-68, (2008).

[4] The Wealth of India, A Dictionary of Indian medicinal plant's raw material and industrial products, 289-290.

[5] M. Boekel, V. Fogliano, N. Pellegrini, C. Stanton, G. Scholz, S. Lalljie. A review on the beneficial aspects of food processing. Nutr Food Res, 54, 1215- 1247, 2003.

[6] C. Manach, A. Scalbert, C. Morand, C. Remesy, L. Jimenez. Polyphenols: food sources and bioavailability. Am. J. Clin. Nutr, 79, 727-747 2004.
[7] V. Neveu, J. Perez-Jim.n ez, F. Vos, V. Crespy, L. du Chaffaut, L. Mennen, C. Knox, R. Eisner, J. Cruz, D. Wishart, A. Scalbert. Phenol-Explorer: an online comprehensive database on polyphenol contents in foods. Database 2010, DOI: 10.1093/database/bap024.

[8] C. A. Rice-Evans, N. J. Miller, G. Paganga. Structureantioxidant activity relationships of flavonoids and phenolic acids. Free Radical Biol. Med, 20, 933-956, 1996.

[9] S. Banerjee, K. Adak, M. Adak, S. Ghosh, A. Chatterjee. Effect of Some Antinutritional Factors on the Bioavailability of Minerals along with the Study of Chemical Constituents \& Antioxidant Property in Typhonium trilobatum \& Spinacia oleracea. Chemical Science Review and Letters, 4(14), 429-439, 2015

[10] S. Banerjee, K. Adak, S. Ghosh, M. Adak, A. Chatterjee.Qualitative and quantitative estimation and characterization of secondary metabolites of typhonium trilobatum and trichosanthes dioica (less focussed edible herbal medicinal plants of bengal) leaf extract. International Journal of Advanced Research. 4, 7, 467476, 2016.

[11] World Health Organization. Medicinal plants in Viet Nam. WHO Regional Publications, WHO Regional Office for the Western Pacific, Manila, Series No. 3, (1990).

[12] K.M. Haldar, P. Ghosh, G. Chandra. Evaluation of target specific larvicidal activity of the leaf extract of Typhonium trilobatum against Culex quinquefasciatus Say. Asian Pac J Trop Biomed, 199-203, 2011.

[13]M. Kandhasamy, K.D. Arunachalam. Efficacy of Typhonium trilobatum (L.) Schott tuber extracts on pathogenic bacteria. Elect J Nat Subs, 3, 1-7, 2008.

[14] S. Shanmugam, P.M. Kalaiselvan, S.K. Selvalumar, K. Rajendran. Ethnomedicinal plants used to cure diarrhea and dysentery in Sivagangai district of Tamil Nadu,India. Int J Res Ayur Pharm, 2, 991-994, 2011.

[15] A. Biswas, M.A. Bari, M. Roy, S.K. Vadra. Inherited folk pharmaceuticals knowledge of tribal people in the Chittagong Hill tracks, Bangladesh. Indian J Trad Know. 9, 77-89, 2010.

[16]H.B. Das, Mojumder K., Datta B.K., Ray D. Ethnobotanical uses of some plants by Tripuri and Reang tribes of Tripura. Nat Prod Rad.; 8: 172-180, 2009.

[17] M. Rahmatullah, L. Rahman, F. Rehana, M.A. Kalpana, M.A. Khatun, R. Jahan. A scientific evaluation of medicinal plants used in the folk medicinal system of five villages in Narsinghdi District, Bangladesh. AmEurasian J Sustain Agric, 4, 55-64, 2010.

[18] C. Y. Hsu, Y. P. Chan, J. Chang Antioxidant activity of extract from Polygonum cuspidatum. Biol Res, 40, 1321, 2007.

[19] B. Matthaus. Antioxidant activity of extracts obtained from residues of different oilseeds. J Agric Food Chem, 50, 3444-52, 2002.

[20] M.A. Ebrahinzadeh, F. Pourmorad, A.R. Bekhradnia. Ironchelating activity screening, phenol and flavanoid contentof some medicinal plants from Iran. Afr $J$ Biotechnol, 32, 43-49, 2008.

[21]I.F. Benzie, J.J. Strain. The ferric reducing ability of plasma (FRAP) as a measure of "antioxidant power": 


\section{International Journal of Science and Research (IJSR) \\ ISSN (Online): 2319-7064 \\ Index Copernicus Value (2015): 78.96 | Impact Factor (2015): 6.391}

The FRAP assay, Analytical Biochemistry, 239, 70-76, 1996.

[22] R.P. Singh, C.K.N. Murthy, G.K. Jayaprakash. Studies on the antioxidant activity of pomegranate (Punicagranatum) peel and seed extracts using in vitro models, Journal of Agricultural and Food Chemistry, 50, 81-86, 2002.

[23] M. Parimala, F.G. Shoba. Phytochemical Analysis and Invitro Antioxidant Activity of Hydroalcoholic Seed Extract of Nymphaea nouchali Burm. Asian Pacific Journal of Tropical Biomedicines, 3, 887-895, 2013.

[24] M. Pineda, M Aguilar. Spectrophotometric Quantitation of Antioxidant Capacity through the Formation of a Phosphomolybdenum Complex: Specific Application to the Determination of Vitamin E. Anal Biochem, 269, 337-341, 1999.

[25] H.Ohkawa, N. Ohishi, K. Yagi. Assay for lipid peroxides in animal tissues by thiobarbituric acid reaction. Anal Biochem, 95, 351, 1979.

[26] V.P. Kumar, S. Shasidhara, M.M. Kumar, B.Y. Sridhara. Effect of Luffa echinata on lipid peroxidation and free radical scavenging activity, $J$ Pharm Pharmacol, 52, 891, 2000.

[27]Y. Mizushima, M. Kobayashi. Interaction of anti-inflammatory drugs with serum preoteins, especially with some biologically active proteins. $J$ of Pharma Pharmacol, 20, 169- 173, 1968.

[28] D.Z. Dimitrova, P. Nedialkov, G. Kitanov. Radical scavenging and antioxidant activities of methanolic extracts from Hypericum species growing in Bulgaria. Pharmacogn mag, 6, 74-80, 2010.

[29] R. Re, N. Pellegrini, A. Proteggente, A. Pannala, Yang, M. Rice-Evans C. Antioxidant activity applying an improved ABTS radical cation decolorization assay. Free Radic Biol Med.; 26: 1231-7, (1999).

[30] S. Naeem, A. Muhammad, M. Asif. Optimization of extraction conditions for the extraction of phenolic compounds from Moringa oleifera leaves. Pak. $J$. Pharm. Sci, 25, 535- 541, 2012.

[31] M.N. Maillard, C. Berset. Evolution of antioxidant activity during kinling: role of insoluble bound phenolic acids of barley and malt. J Agric Food Chem, 43, 178993, 1995.

[32] C. Ross, C. Hoye, V. Chistina. Influence of Heating on the Polyphenolic Content and Antioxidant Activity of Grape Seed Flour. Journal of Food Science, 76, 6, c884-c890, 2011.

[33] T. Sathishkumar, R. Baskar, S. Shanmugam, P. Rajasekaran, S. Sadasivam, V. Manikandan. Optimization of flavonoids extraction from the leaves of Tabernaemontana heyneana Wall. using L16 Orthogonal design. Nature and Science, 6, 10 - 21, 2008.

[34] H. Li, J. Xua, Y. Liu, S. Ai, F. Qin, Z. Li. Antioxidant and moisture-retention activities of the polysaccharide from Nostoc commune. Carbohydr. Polym, 83, 18211827, 2011.

[35] M. Parimala, F.G. Shoba. Phytochemical Analysis and Invitro Antioxidant Activity of Hydroalcoholic Seed Extract of Nymphaea nouchali Burm. Asian Pacific Journal of Tropical Biomedicines, 3, 887-895, 2013.

[36] J.T. Coyle, P. Puttfarchen. Oxidative stress, glutamate and neurodegenerative disease. Science, 209, 1184, 1993.
[37] J.M. Braugghler, C.A. Duncan, L.R. Chase. The involvement of iron in lipid peroxidation. Importance to ferrous to ferric iron in initiation. $J$ Biol chem, 261, $10282,1986$.

[38]I.F. Benzie, J.J. Strain. The ferric reducing ability of plasma (FRAP) as a measure of "antioxidant power": The FRAP assay, Analytical Biochemistry, 239, 70-76, 1996.

[39] M.Pineda, M. Aguilar. Spectrophotometric Quantitation of Antioxidant Capacity through the Formation of a Phosphomolybdenum Complex: Specific Application to the Determination of Vitamin E. Anal Biochem, 269, 337-341, 1999.

[40]Y. Mizushima, M. Kobayashi. Interaction of anti-inflammatory drugs with serum preoteins, especially with some biologically active proteins. $J$ of Pharma Pharmacol, 20, 169- 173, 1968. 